\title{
ANALÝZA EKVIVALENTNÍ ŠÍŘKY DIAGONÁLNÍ VZPĚRY ZTUŽUJÍCÍ STĚNY S OTVOREM
}

\author{
ANALYSIS OF THE EQUIVALENT DIAGONAL STRUT WIDTH OF \\ INFILL SHEAR WALL WITH AN OPENING
}

\author{
Ondřej Šimek ${ }^{*}, 1$, Miloš Zich ${ }^{1}$ \\ "simek.o@fce.vutbr.cz \\ ${ }^{1}$ Vysoké technické v Brně, Fakulta stavební, Veveří 331/95, 60200 Brno
}

\begin{abstract}
Abstrakt
Předmětem článku je porovnání chování prefabrikovaných ztužujících železobetonových výplňových stěn s otvorem pro různé typy vyztužení. Jedná se o stěny, které mohou zajištovat tuhost konstrukce skeletového typu proti vodorovnému zatížení. Zkoumané stěny s otvorem představují př́ípady, jak může být stěna vyztužena před dodatečným provedením otvoru. Je zde studován vliv tzv. „spící výztuže“. To je výztuž, která začne působit až po dodatečném provedení otvoru. Na základě již publikovaných výsledků experimentu a jeho následné ověření numerickými modely je provedena parametrická studie, $\mathrm{v}$ rámci které je studován vliv velikosti otvoru $\mathrm{v}$ těchto ztužujících stěnách na jejich únosnost a tuhost. V poslední řadě je provedeno srovnání získaných výsledků s dostupnou literaturou.
\end{abstract}

\section{Klíčová slova}

ztužující výplňová stěna, vyztužení, konstrukční zásady, prefabrikát, otvor

\begin{abstract}
The subject of the article is a comparison of behavior of a precast reinforced concrete infill shear walls with an opening with different types of reinforcement. These are the walls that can ensure stiffness of the frame structure against horizontal load. Studied walls with an opening represent cases of how the wall can be reinforced prior to the implementation of an additional opening. The influence of the so called "sleeping reinforcement" is studied. This is a reinforcement that would take effect only after the additional opening has been made. Based on the already published results of the experiment and subsequent verification with numerical models, a parametric study is performed, where the influence of an opening size in these infill shear walls is studied on their load - bearing capacity and stiffness. Lastly, a comparison of the obtained results with available literature is made.
\end{abstract}

Key words

infill shear wall, reinforcement, detailing of reinforcement, precast element, opening

\section{1 ÚVOD}

V budovách, jejíž nosnou konstrukci tvoří železobetonový skelet, jsou často umístěny železobetonová jádra nebo železobetonové výplňové stěny, jejichž úkolem je zajištění patřičné tuhosti konstrukce proti vodorovnému zatížení, například větru či zemětřesení. Ztužující výplňové stěny bez otvoru, pokud nejsou tuze spojeny po obvodě s ohraničující skeletovou konstrukcí, jsou prvky namáhané převážně tlakem. Tato skutečnost umožňuje často návrh těchto stěn z prostého nebo slabě vyztuženého betonu.

Může se stát, že vznikne potřeba vyřezat do takové stěny otvor, at' už z technologických nebo dispozičních důvodů. Pokud se tak stane, je třeba znovu posoudit nově vzniklé namáhání stěny, stejně tak jako nové globální působení celé konstrukce budovy, jejíž ztužující systém byl touto úpravou oslaben.

Cílem námi provedené studie je ověření chování ztužujících železobetonových výplňových stěn s otvorem. Mimo to je ověřen vliv různých způsobů vyztužení stěn. Studie je provedena na samostatných stěnách, které představují betonový prefabrikát, umístěný v železobetonovém skeletu. Stěny byly vyzkoušeny v laboratořích Admas na VUT v Brně. Po provedení experimentů bylo chování stěn ověřeno výpočetními modely v softwaru ATENA [10]. Cílem projektu bylo získat relevantní data k ověření vhodného způsobu vyztužování a navrhování obdobných stěn s implementací tzv. „spící výztuže“. To je taková výztuž, která by byla předem nachystaná v plné 
stěně bez otvoru již od fáze výroby a začala by přispívat k únosnosti a tuhosti stěny po dodatečném provedení otvoru. Alternativně lze uvažovat i s dodatečně vlepovanou výztuží.

Pro ověrení namáhání stěn s otvorem byly analyzovány 4 typy samostatných stěn, které byly různě vyztuženy, Obr. 1. Stěny jsou různě vyztuženy: od jednoduchého vyztužení kari sítí (Obr. 1a) nebo kombinací kari sítě a obvodové výztuže (Obr. 1b). Tyto dva př́pady simulují situaci, kdy by stěna nebyla vyztužena „spící výztuži“, tedy bez vyztužení kolem uvažovaného nově vzniklého otvoru. Další dva vzorky jsou vyztuženy kari sítí s obvodovou výztuží a výztuží kolem otvoru, v jednom případě šikmou výztuží (Obr. 1c), v druhém vodorovnými a svislými pruty (Obr. 1d).

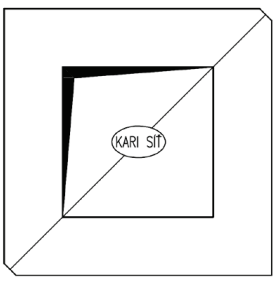

a) Stěna SV1.

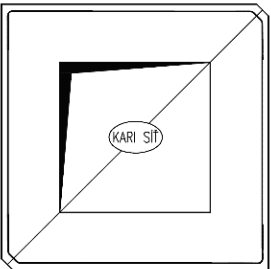

b) Stěna SV2.

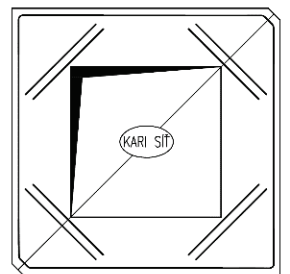

c) Stěna SV3.

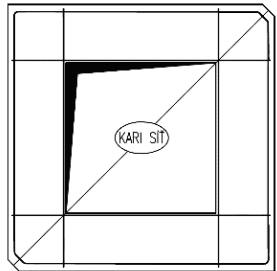

d) Stěna SV4.

Obr. 1 Typové vyztužení analyzovaných stěn.

\section{LITERÁRNÍ PŘEHLED/POPIS SOUČASNÉHO STAVU}

Jednoduchá implementace ztužující výplňové stěny do výpočtového modelu navrhované rámové konstrukce v praxi (např. prutového) může spočívat v nahrazení stěny kloubově připojenou náhradní diagonální vzpěrou, Obr. 2a. Nahrazující vzpěra představuje tuhost skutečné ztužující výplňové stěny která je součástí skeletové konstrukce, Obr. 2b. Tuto úvahu první adoptoval Polyakov [4], později byla dále rozvedena např. Stafford-Smith a Carter [5], viz Tab. 1 a dalšími. Návrh takových stěn je rovněž popsán v literatuře pro projekční praxi, např. [9].

Tab. 1 Výpočet ekvivalentní šířky vzpěry pro stěnu bez otvoru.

\begin{tabular}{ccc}
\hline Literatura & Výpočetní vztah & Ozn. \\
\hline & $w / d=a \lambda H^{b}$ & (1) \\
Stafford-Smith a & Pozn. : Pro poměry stran stěny $1: 1$ & \\
Carter $1969[5]$ & $a$ úrovneň napětí ve stěně $10 \% j e$ \\
& $a=0,521 ; b=-0,298$ \\
\hline
\end{tabular}

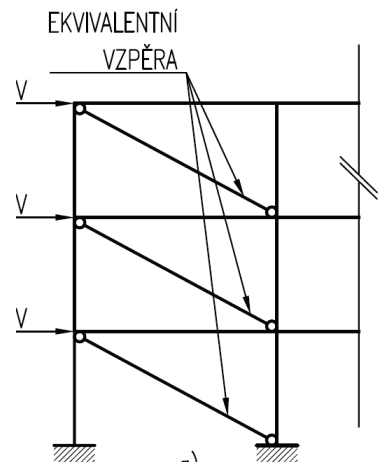

a)

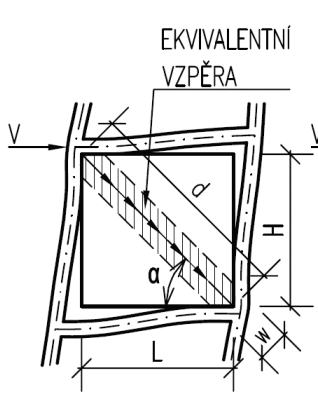

b)

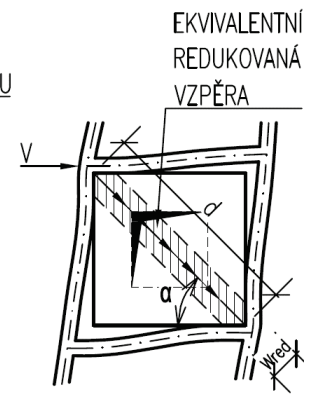

d)

Obr. 2 Role ekvivalentní diagonální vzpěry ve ztužující výplňové stěně. 
Při provedení dodatečného otvoru je tato ekvivalentní diagonála přerušena a silový tok musí proudit kolem nově vytvořeného otvoru, Obr. 2c. V duchu zachování jednoduchosti pro použití v běžné projekční praxi, je možno i stěnu s otvorem uvažovat v modelu pro globální chování konstrukce jako ekvivalentní vzpěru, avšak s redukovanou velikostí, Obr. 2d. Popsanou úvahou se zabývali např. Al-Chaar a kol. [6], Mondal a kol. [7], Asteris a kol. [8] a Cetisli [9], kteří se zabývali především vlivem velikostí otvoru ve ztužující stěně na míru redukce velikosti ekvivalentní vzpěry, viz Tab. 2. Śřrka redukované vzpěry se následně vypočte dle vztahu (2).

$$
w_{\text {red }}=w \cdot \chi_{w, \text { red }}
$$

Kde $w_{\text {red }}$ je ekvivalentní redukovaná šířka vzpěry stěny s otvorem; $w$ je ekvivalentní šířka vzpěry stěny bez otvoru; $\chi_{w, r e d}$ je součinitel redukce šířky vzpěry.

Tab. 2 Srovnání výpočtu součinitele redukce šířky vzpěry.

\begin{tabular}{|c|c|c|}
\hline Literatura & Výpočetní vztah & Ozn. \\
\hline $\begin{array}{c}\text { Al-Chaar } 2003 \\
{[6]}\end{array}$ & $\chi_{w, \text { red }}=0,6 \mu_{o}^{2}-1,6 \mu_{o}+1$ & (3) \\
\hline Mondal 2008 [7] & $\chi_{w, \text { red }}=1-2,6 \mu_{o}$ & (4) \\
\hline Asteris 2012 [8] & $\chi_{w, \text { red }}=1-2 \mu_{o}^{0,54}+\mu_{o}^{1,14}$ & (5) \\
\hline Cetisli 2015 [9] & $\begin{array}{c}\chi_{w, \text { red }}=1-2 \mu_{o}^{0,5 k_{1} k_{2}}+\mu_{o}^{k_{1} k_{2}} \\
\text { Pozn. : Pro otvory umistěné prostřed stěny: } k_{1}=1+0,4 \frac{L}{H} ; k_{2}=1,0\end{array}$ & (6) \\
\hline $\begin{array}{l}\text { Výpočet } \\
\text { součinitele } \\
\text { velikosti otvoru } \\
\mu_{0}\end{array}$ & $\begin{array}{c}\qquad \mu_{0}=\frac{A_{\text {otvor }}}{A_{\text {plná stěna }}} \\
A_{\text {otvor } \ldots \text { plocha otvoru; }} A_{\text {plná stěna } \ldots \text { plocha stěny bez otvoru }}\end{array}$ & (7) \\
\hline
\end{tabular}

\section{ANALÝZA EXPERIMENTU V SOFTWARU ATENA}

Pro analýzu experimentu a následné vytvoření výchozích modelů pro následující parametrickou analýzu byl zvolen program Atena. Byla maximální snaha vystihnout okrajové podmínky experimentu, rozdílné materiálové parametry a vliv rozdílného typu vyztužení. Vhodnost použití tohoto softwaru byla ověřena v [3], kde byl model v softwaru Atena srovnán s dalšími dvěma výpočetními modely. Pro modelování experimentů stěn byly použity normové materiálové charakteristiky betonářské výztuže dle [1] z důvodu absence zkoušek materiálů výztuže. Pro modely byl použit bilineární pracovní diagram výztuže. Mez kluzu byla 550 MPa pro všechny výztuže, mez pevnosti byla $578 \mathrm{MPa}$ pro kari sítě a $594 \mathrm{MPa}$ pro vázané výztuže. Pevnost betonu daných vzorků v čase experimentu byla použita na základě zkušebních těles. Krychelná tlaková pevnost betonu v čase provádění experimentu se pohybovala mezi 55-63 MPa v závislosti na zkoušeném vzorku. Výztuž byla modelována diskrétně, ve své skutečné poloze a se shodnými detaily a provázáními, tak jak byla navržena ve fázi projektu, viz Obr. 1. Pro modely byl použit materiálový model nezafixovaných trhlin, soudržnost mezi betonem a výztuží byla modelována dle Bigaj 1999 [11]. Hodnoty lomové energie betonu byly stanoveny dle MC1990 [2]. Popis všech materiálových modelů lze nalézt v [11].

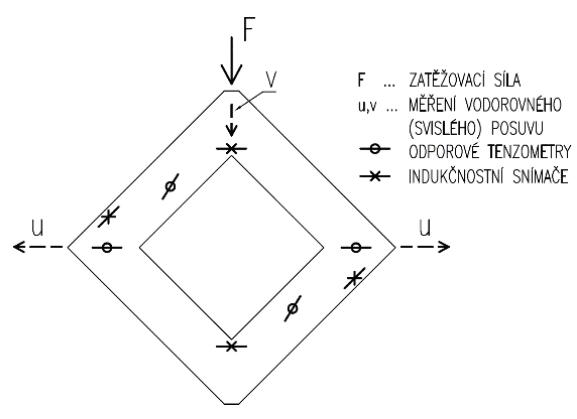

Obr. 3 Schéma měřičských bodů.

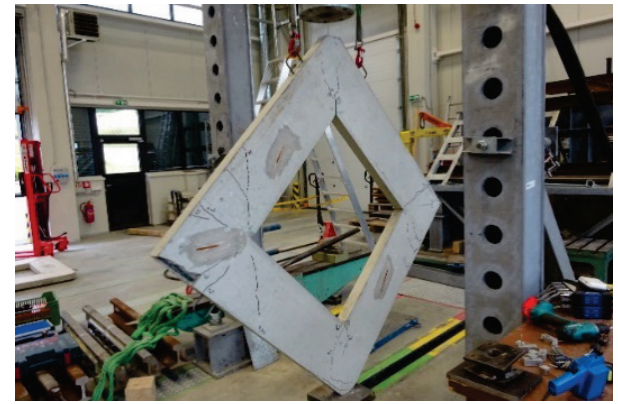

Obr. 4 Foto experimentu stěny. 


\section{STUDIE VLIVU VELIKOSTI OTVORU}

Po vzájemné korelaci výsledků analýzy a experimentu, byla provedena parametrická studie vlivu velikosti otvoru ztužující železobetonové výplňové stěny na její únosnost a tuhost. Stěny podrobené analýze byly rozměrů $3000 \times 3000 \mathrm{~mm}$ o tloušt'ce $300 \mathrm{~mm}$ (běžné rozměry reálné stěny v praxi). Vliv velikosti otvoru byl ověřován pro případy plochy otvorů 5 až 50 \% plochy stěny. Otvor byl čtvercového rozměru, situován ve středu stěny, Obr. 6 . Okrajové podmínky, materiálové modely a nastavení výpočtového řešiče byly odvozeny z modelů, které sloužily k ověření výsledků experimentu. Srovnání bylo provedeno pro tř́ídu betonu C30/37, která je běžná pro výrobu prefabrikátů. Pro modely je použito středních hodnot materiálových parametrů.

Vyztužení bylo voleno tak, aby plocha tahové výztuže splňovala minimální požadavky, které předepisuje norma EN 1992 [1]. Kari sítě analyzovaných modelů byly Ø6 s oky 150×150 mm. Doplňující vázané výztuže byly voleny takového průměru, aby výsledná plocha tahové výztuže (kari sítě s vázanou výztuží) byla přesně As,min. Potom lze prvek posuzovat jako železobetonový. Vzhledem k rozměrům stěny byly všechny výztuže uvažovány ve dvou vrstvách (1 vrstva výztuže u každého povrchu). Typ vyztužení jednotlivých analyzovaných vzorků je stejný jako u vzorků pro experimenty, viz Obr. 1 .

\section{Únosnost výplňové ztužující stěny}

Na Obr. 5 je ukázán vliv velikosti otvoru na celkovou únosnost stěny. Otvor velikosti $0 \%$ a síla $\mathrm{F}=100 \%$ znázorňují stěnu bez otvoru, zde má rozdílné vyztužení zanedbatelný vliv. Otvory o velikosti 5-10 \% ve stěnách SV3 a SV4 mají za následek snížení únosnosti do $90 \%$ únosnosti plné stěny. U stěn SV1 a SV2 s otvorem $5 \%$ je únosnost do 80 \%. Př́i zvětšení otvoru na $10 \%$ se únosnost razantně sníží (65 \% únosnosti pro SV2 a $50 \%$ pro SV1). Únosnost stěn SV3 a SV4 s velikostí otvoru $20 \%$ má za následek snížení únosnosti na cca 50 \% hodnoty únosnosti stěny bez otvoru. Pro stěnu SV2 je to $30 \%$, pro SV1 pak $20 \%$. Při této velikosti otvoru lze pozorovat největší rozdíly mezi únosnostmi popisovaných vzorků. Analyzované stěny s největšími otvory (40-50 \%) dosáhly únosnosti kolem 5-10 \% původní hodnoty (bez otvoru) pro všechny typy vyztužení.

Z výše popsaných výsledků je zřejmé, že rozdílný typ vyztužení má nezanedbatelný vliv na únosnost ztužujících výplňových stěn při menších velikostech otvorů stěny (5-10 \%). Při větších plochách otvorů (15-25 \%) jsou tyto rozdíly mezi jednotlivými vzorky největší. Při největším otvoru (50\%) už rozdíly v únosnosti mezi jednotlivými stěnami prakticky nejsou. Rozdíly lze porovnat na Obr. 5.

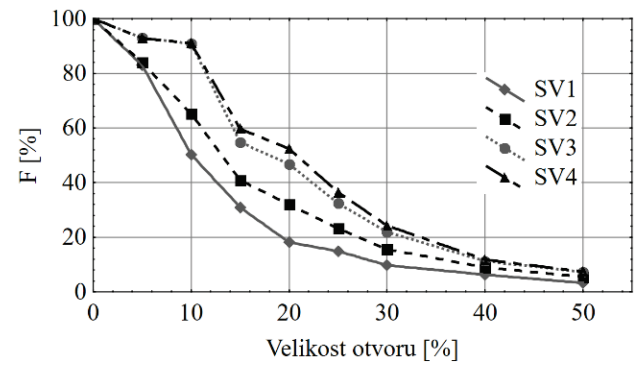

Obr. 5 Vliv velikosti otvoru na únosnost.

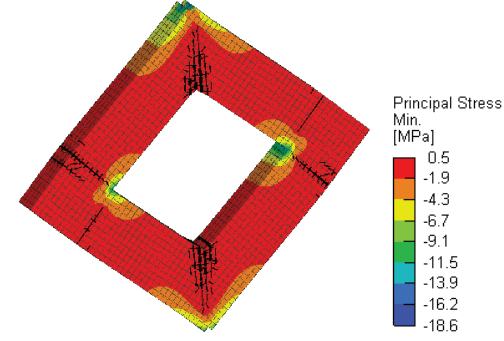

Obr. 6 Výpočetní model stěny (otvor $25 \%$ ).

\section{Tuhost výplňové ztužující stěny}

V další části je porovnáván vývoj tuhosti konstrukce v průběhu jejího zatěžování a postupného změkčování vlivem rozvoje trhlin. Každý graf (Obr. 7a-d) je vyobrazen pro všechny typy stěn s jednou velikostí otvoru. Aby bylo možné podrobně sledovat vývoj tuhosti stěny, byla vypočtena tečnová tuhost $\mathrm{K}_{\mathrm{t}}$ podle $(1) . \Delta \mathrm{F}$ a $\Delta \mathrm{v}$ jsou př́růstky působící svislé síly a svislé deformace měřené v místě působící zatěžovací síly. Takto je znázorněna tuhost ekvivalentní diagonální vzpěry.

$$
K_{t}=\Delta F / \Delta v
$$

Počáteční tuhost, při malých úrovních zatížení, kdy nevznikají trhliny je pro všechny typy rozdílně vyztužených stěn s otvory totožná $\left(\mathrm{K}_{\mathrm{t}}=100 \%\right.$ ). Jediný rozdíl je však v př́ispěvku výztuže k celkové tuhosti stěny, ten je však zanedbatelný. 
Vývoj tuhosti v průběhu zvyšování síly a změkčování konstrukce je pro stěny SV3 a SV4 téměř totožný pro jednotlivé případy velikosti otvoru. Po vzniku prvních trhlin je zřejmý vyšší pokles tuhosti pro stěny SV2 a SV1 (méně vyztužené) oproti SV4 a SV3 (více vyztužené).

Pro velikost otvoru $5 \%$, se stěny SV1 a SV2 chovají téměř identicky. Pokles tuhosti v tomto př́padě je $25 \%$ oproti více vyztuženým SV3(4). Snížení tuhosti v případě velikosti otvoru 10 \% je pro SV2 o $30 \%$ a pro SV1 o 40 \% oproti SV3(4). Při velikosti otvoru $25 \%$ se tyto rozdíly zmenšují (pokles tuhosti je pro SV2 o $15 \%$ a pro SV1 o $30 \%$ oproti SV3(4)). V prípadě velmi velkých otvorů (40\% plochy stěny) je pokles tuhosti pro SV2 o $10 \%$ a pro SV1 o 15 \% oproti SV3(4)). Rozdíly jsou odečteny v bodě největšího rozdílu tuhostí stěn.

Vývoj tuhosti pro stěnu SV1 bude rychleji klesat oproti prezentovaným hodnotám, jelikož výsledky analýzy svislé deformace modelu tohoto prvku byly rozdílné o $40 \%$ oproti experimentálně naměřným hodnotám.

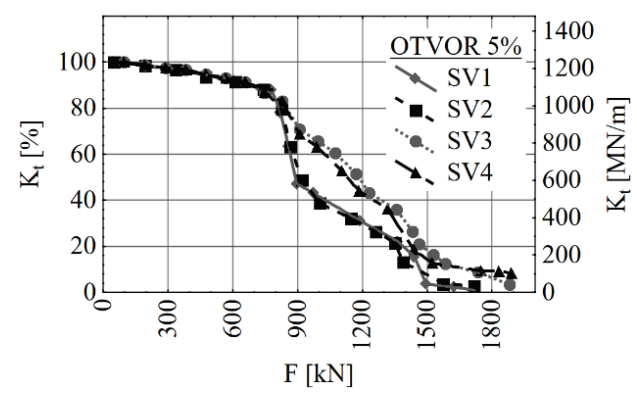

a) otvor $5 \%$.

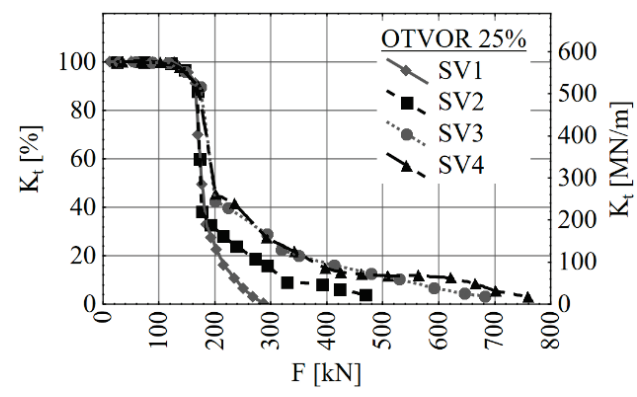

c) otvor $25 \%$.

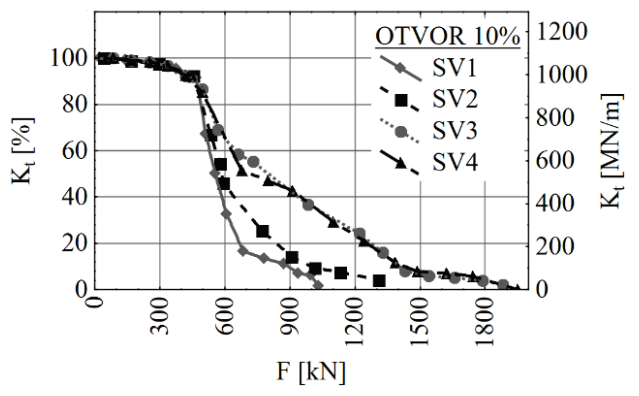

b) otvor $10 \%$.

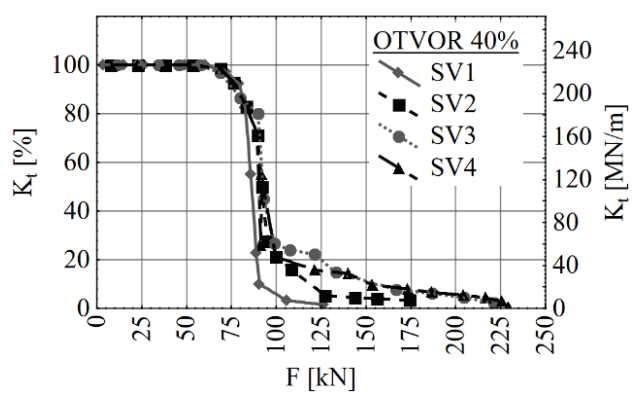

d) otvor $40 \%$.

Obr. 7 Vývoj tuhosti stěn v závislosti na síle pro různé velikosti otvoru.

\section{DISKUZE}

Dosud publikované studie odvozují velikosti šírky ekvivalentních vzpěr stěn s otvorem pro úrovně napětí, kdy nevznikají trhliny (10 \% únosnosti stěny). Je zřejmé, že tuhosti jednotlivých vzorků se ve vyšších úrovních napětí budou lišit v závislosti na vyztužení, viz Obr. 7. Doposud však neexistují studie, které by tento tuto oblast zkoumaly pro případ stěn s otvorem. Porovnání dosud publikovaných výpočetních vztahů bude tedy provedeno pro úroveň napětí $10 \%$ únosnosti stěny. Vzorky SV1-4 není třeba v tomto porovnání rozlišovat, protože vliv vyztužení v tomto úrovní napětí je zanedbatelný (viz kap. 4). Redukovaná šiřka vzpěry pro analyzované modely je spočítána dle (9).

$$
w_{\text {red }}=\frac{K_{t} d}{E_{v} b}
$$

Kde $w_{\text {red }}$ je ekvivalentní redukovaná šířka vzpěry stěny s otvorem; $K_{t}$ je tečnová tuhost stěny; $d$ je délka ekvivalentní vzpěry; $E_{v}$ je modul pružnosti betonové výplně; $b$ je tloušt'ka výplně. 
Na Obr. 8 je znázorněno porovnání velikosti šířky ekvivalentní vzpěry z analýzy ze softwaru Atena a jednotlivých šířek vzpěr obdržených od publikovaných autorů. Jako výpočet šiřky vzpěry plné stěny, která musí být použita pro následující výpočet šírky vzpěry stěny s otvorem, je použit vztah (1) dle [5] na základě porovnání s ostatními publikovanými studiemi, které se zabývají šířkou vzpěry plné stěny bez otvoru. Porovnání těchto studií není součástí tohoto článku. Rozdíly výsledků pro vyšetřované velikosti otvoru jsou do $40 \%$. Nejblíže k získaným výsledkům je výpočetní vztah od Mondal [7], kde je rozdíl 1-16 \% oproti získaným hodnotám ze softwaru Atena. Výpočetní vztah tohoto autora však nedefinuje velikost šírky vzpěry pro velikosti otvoru nad 38 \% (předpokládá se, jako by stěna již tuhostí nepřispívala). Dalším je vztah od Asteris [8], kde jsou rozdíly 4-33 \%, oproti hodnotám získaným ze softwaru Atena. Výpočetní vztahy dalších autorů dosáhly horších korelací naměřených výsledků, s rozdílem průměrně $40 \%$ pro Al-Chaar [6] a $33 \%$ pro Cetisli [9].

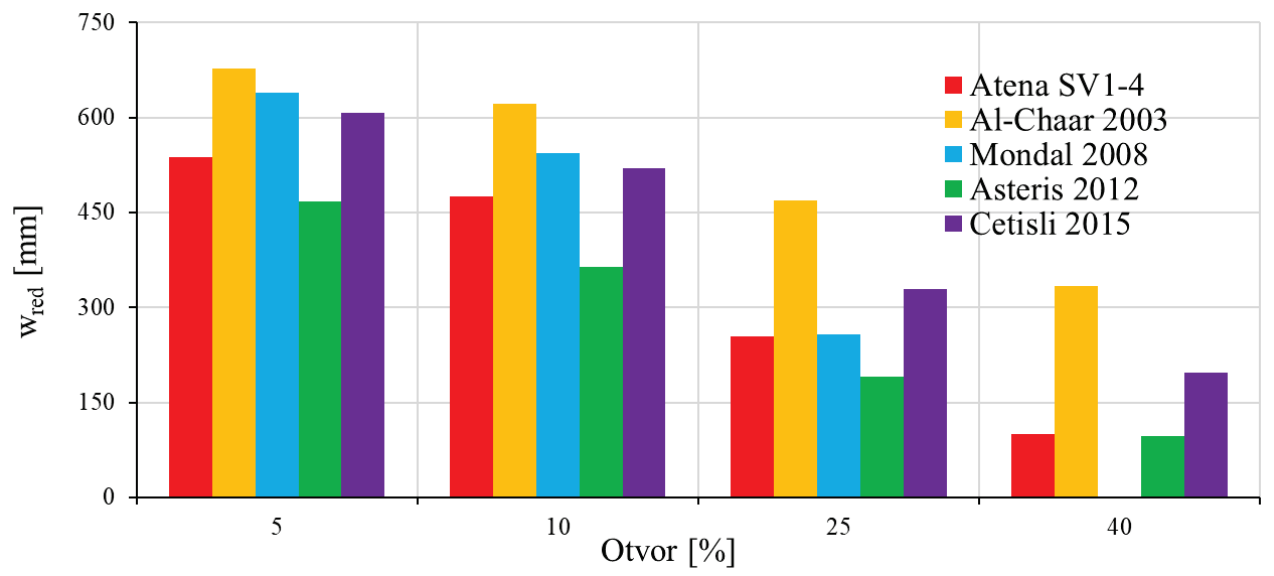

Obr. 8 Velikost šírky ekvivalentní vzpěry stěny s otvorem pro úroveň napětí $10 \%$.

\section{ZÁVĚR}

Byla provedena parametrická studie, kde byl studován vliv rozdílných typů vyztužení ztužujících železobetonových výplňových stěn s otvorem na jejich únosnost a tuhost. Z výše prezentovaných výsledků je zřejmé, že zkoumané rozdílné typy vyztužení těchto stěn s otvorem má nezanedbatelný vliv na jejich únosnost i tuhost. Tyto rozdíly v únosnostech i tuhostech se projevují již při malých velikostech otvorů (5-10 \%). Největších rozdílů dosahují stěny při středních velikostech otvoru (15-25\%). Při nadměrně velkých otvorech (40-50\%) se rozdíly únosnosti i tuhosti mezi jednotlivými vzorky zmenšují k zanedbatelným hodnotám.

Výsledky získané touto studií byly v omezeném rozsahu porovnány s dostupnou literaturou. Předpokládá se, že prezentované již publikované výpočetní vztahy budou použity pro následné odvození vztahů, které budou zahrnovat vliv úrovně napětí ve ztužujících železobetonových výplňových stěnách s otvorem a různými typy vyztužení na redukovanou ekvivalentní šířku vzpěry.

\section{Poděkování}

Článek byl řešen v rámci projektu FAST-J-20-6438 Vliv šikmé výztuže v rozích dodatečně provedeného otvoru.

\section{Použité zdroje}

[1] ČSN EN 1992-1-1 ed. 2: Eurokód 2: Navrhování betonových konstrukcí - Č́st 1-1: Obecná pravidla a pravidla pro pozemní stavby. Praha: ÚNMZ, 2011.

[2] CEB-FIP Model Code 1990: Design Code, 1993. London: T. Telford. ISBN 0727716964.

[3] ŠIMEK, Ondřej a Miloš ZICH. Únosnost ztužujících železobetonových stěn s otvorem. In: Sborník konference JUNIORSTAV 2021. Brno, 2021, s. 207-211. ISBN 978-80-86433-75-2.

[4] POLYAKOV, S. V. Masonry in framed buildings. Moscow: Gosudarstvennoe isdatel'stvo Literatury pro 
stroitel'stvu i arckhitecture, 1956. ISBN 978-0853500803.

[5] STAFFORD SMITH, B a C CARTER. A METHOD OF ANALYSIS FOR INFILLED

FRAMES. Proceedings of the Institution of Civil Engineers [online]. 1969, 44(1), 31-48 [cit. 2021-55]. ISSN 1753-7789. Dostupné z: doi:10.1680/iicep.1969.7290.

[6] AL-CHAAR, Ghassan, Daniel ABRAMS a Gregory LAMB. Effect of Openings on Structural Performance of Unreinforced Masonry Infilled Frames. ACI 211 [online]. 2003 [cit. 2021-05-12]. Dostupné z:

https://www.researchgate.net/publication/265562695_Effect_of_Openings_on_Structural_Performanc e_of_Unreinforced_Masonry_Infilled_Frames

[7] MOND $\bar{A} L$, Goutam a Sudhir K. JAIN. Lateral Stiffness of Masonry Infilled Reinforced Concrete (RC) Frames with Central Opening. Earthquake Spectra [online]. 2008, 24(3), 701-723 [cit. 2021-5-12]. ISSN 8755-2930. Dostupné z: doi:10.1193/1.2942376.

[8] G. ASTERIS, Panagiotis, Ioannis P. GIANNOPOULOS a Christis Z. CHRYSOSTOMOU. Modeling of Infilled Frames With Openings. The Open Construction and Building Technology Journal [online]. 2012, 6(1), 81-91 [cit. 2021-5-12]. ISSN 18748368. Dostupné z: doi:10.2174/1874836801206010081

[9] CETISLI, Fatih. Effect of openings on infilled frame stiffness. Gradevinar 67 [online]. 2015, (6), 787-798 [cit. 2021-05-12]. Dostupné z: https://www.researchgate.net/publication/280036445_Effect_of_openings_on_infilled_frame_stiffnes $\mathrm{s}$

[10] ELLIOTT, Kim S. a Colin K. JOLLY. Multi-storey precast concrete framed structures. [Second edition]. Chichester: Wiley-Blackwell, 2013. ISBN 978-1-4051-0614-6.

[11] ČERVENKA, Vladimír, Libor JENDELE a Jan ČERVENKA. ATENA Program Documentation: Part 1 Theory [online]. [cit. 2021-05-17]. Dostupné z: https://www.cervenka.cz/assets/files/atenapdf/ATENA_Theory.pdf. 